RESEARCH REPORT

\title{
FACTORS EFFECTING MOTIVATION AND SATISFACTION OF TEACHERS OF HEARING IMPAIRED
}

\begin{abstract}
\section{Objective}

This study aimed at investigating motivational factors for improved job satisfaction of teachers working in special schools for hearing impaired children in the Punjab province of Pakistan.
\end{abstract}

\section{Study Design and Sampling Techniques}

Being qualitative in its nature, this study explored in depth responses of teachers selected purposively.

\section{Participants}

The participants comprised both genders with a teaching experience of more than ten years in any educational institute rendering services for education of hearing impaired students.

\section{Data Collection Tools}

Focus group discussions were arranged and a semi structured interview guide was used to elicit in-depth responses of the participants. These responses were then transcribed and thematically analyzed.

\section{Results}

Gazetted post, high pay scale, recognition, serving persons with disability and less working hours came out as the motivating factors, whereas improper student placement, lack of appreciation from administration, stress level, low job status, low respect level emerged as major job dissatisfying factors for the teachers of children with hearing impairment.

\section{Conclusion}

The stakeholders must be aware of top motivational factors and try to nourish them. Non motivating factors should be minimized for teachers of hearing impaired children for their retention and prosperous organizational atmosphere which will ultimately lead to better student achievement.

\section{Keywords}

Hearing Impaired, Teacher Motivation, Job Satisfaction, Special Education, Job Stress, Recognition, Disability

\author{
Abdul Aziz \\ M. Phil Scholar \\ Department of Sociology \\ Bahauddin Zakariya University, \\ Lahore Campus \\ Makasher1982@gmail.com \\ Faiza Saeed \\ M. Phil Scholar \\ Department of Special Education \\ Bahauddin Zakariya University, \\ Lahore Campus \\ zoologist_fsc@yahoo.com

\section{Muhammad Saeed \\ PhD Scholar \\ Department of Special Education University of the Punjab, \\ Lahore \\ pk.saeed@gmail.com}

[Aziz A, Saeed F, Saeed M. Factor Effecting Motivation and Satisfaction of Teachers of Hearing Impaired. Pak.j.rehabil. 2015; 4(1):29-36] 


\section{INTRODUCTION}

Motivation is a goal directed behavior because the motivational concept is used to point up the factors within an individual, which stimulate, maintain and direct behavior and abilities towards a goal'.

Job satisfaction is the intensity to which a teacher has encouraging or optimistic feeling about job or the career ${ }^{2}$. So job plays a vital role in life, it takes a lot of time and provides people with the financial needs. Hence, the perception of teacher's job must be attractive and accomplish their contentment and satisfaction ${ }^{3}$.

Our actions and efforts are influenced to great extent by means of motivation. A highly motivated group of teachers assists in obtaining the targets of an organization or institution. When organizations are competent enough, and goals are specified, to compete with the competitors in a better way, and self-confidence or morale is also higher when teachers are highly motivated. Teachers for hearing impaired children and other employees working in an institute are the central power of the success and achievement of any institution. If the institution does not recognize the hard work and contributions of its human resources and reward them accordingly, it would not be able to get the better outcomes and highest level of motivation and job satisfaction of the human resources. Recognition and reward are valuable to the staff in a way that it stimulates self-reliance ${ }^{4}$.

The progress towards human relationships throws more light on the significance of the morale and betterment of the work conditions for the staff of the institutions and organizations at growing output as by fulfilling all needs, satisfaction can be attained ${ }^{5}$.

It is considered that satisfaction while teaching the hearing impaired students may influence different aspects of employment such as output, efficiency, retention at job, and finally human resources' well-being ${ }^{6}$.

Motivation and satisfaction to teach special children are very much essential in lives of teachers because they formulate the basic cause for working in life. In this perspective, job satisfaction is the ability of the job to fulfill needs and develop the job performance ${ }^{7}$. Further research on teacher motivation and job satisfaction suggests that most special educators are mainly satisfied from the teaching itself and dissatisfied from their improper promotion channels and salary ${ }^{8-10}$.

The researchers inquire to find out this issue among special educators teaching students with hearing impairment because it is noted that there is plenty of research work available on the topic of teacher motivation and job satisfaction in general educa- tion. But the research work in special education in Punjab, Pakistan is very rare. Department of Special Education, Govt. of Punjab was established in 2003. So, research work in this sector is infrequent. The present study aims at investigating motivation and satisfaction level, particularly in special education teachers of hearing impaired children.

If we conclude motivation and satisfaction concepts, David Myers ${ }^{11}$ mentions that motivation is a need or desire that boosts the performance and to direct it towards the goal. It is the inner succession that makes an individual move in the direction of a goal. Locke ${ }^{12}$ mentions that job satisfaction is a pleasant expressive condition from the appraisal of teacher's work or skill. Job satisfaction can be analyzed by teacher's expectations, importance, reward and recognition ${ }^{13}$. According to Menlo ${ }^{14}$, job satisfaction for teachers is the level where they attain the desired achievements of their students. The respect while having good achievements of students gives value to the teachers and they feel satisfaction from their job. As this study conducted in special education that is the meaningful planned involvement to avoid, and prevail over the hurdles and hindrances that might carry on a person with disabilities from acquiring knowledge and education from complete active participation in an institution and society. It is a complicated speculation that can be evaluated from many perspectives. A special education teacher is a person who needs an extra support, technologies, advanced trainings and workshops on disabilities in order to educate their students according to their disability ${ }^{15}$. A generic term Children with Hearing Impairment include both who are deaf and those who are hard of hearing and refer to students with any kind of hearing loss that interferes with progress or adversely affect educational performance ${ }^{16}$. The researchers aimed to explore qualitatively the motivational factors and job satisfaction level of the teachers of hearing impaired students working in special education schools of the Punjab province of Pakistan

There involve many different factors which affect the performance of a teacher. The various theories give a sketch about performance and behavior of persons they show in certain circumstances and specify factors which motivate them towards a desired goal ${ }^{17}$. Above all, the most significant theory was offered by Abraham Maslow $(1943,1970)$ that was named as Need-Based Theory of Motivation. Need-Based theory depicts hierarchy of factors that causes motivation of teachers or employees in an institution ${ }^{18}$. In any educational institution or organization, a teacher, first of all motivated on account of physiological factors that is food, clothing, shelter and others or in brief he needs salary to accomplish the basic requirements.

The job satisfaction of teacher of hearing impaired children in an institution is also influenced by a 
variety of factors. However, in fact, a pleased and satisfied teacher or worker is a worthy asset for the institution ${ }^{19}$.

Stimulated with motivation endeavor and improves job satisfaction. When workers are supportive and compassionate and their centre of attention is motivational factors, the result is more prolific and productive due to dedication of the employees ${ }^{20}$.

The two-factor theory is formulated by Herzberg ${ }^{21}$, describes about need accomplishment because of their attention into effort best to please or satisfy workers. This theory investigates those factors that cause job satisfaction and also explores those hygiene factors that cause teachers or workers to be dissatisfied. The main hygiene factors such as management, departmental policies, supervision salary, interpersonal relations with administrator and work environment are all connected with job satisfaction. Moreover he mentions motivational factors which construct hard working attitude among the teachers or other staff members and further describe that those factors are associated with job frame work or work of teachers they actually do and categorized them as; appreciation, accomplishment and achievement, work with autonomy, liability or responsibility and infringement is represented to gain and to meet the challenges they have to face while performing job duties. Teacher's development, self-sufficiency, responsibility, is considered to be the motivating factors.

Awarding the incentives and monetary benefits to the teachers properly as by arranging some annual functions enhances the worth of reward without any significant show the reward loses its worth. When teachers or employees get award with more appreciation and regard wonderful delight and pleasure then recipient receive high level of motivation ${ }^{22}$.

The significant motivational factors that affect job satisfaction are appraisal practices, reward and recognition. Recognition is a societal phenomenon of positive reception and appreciation provided by a group to persons who assumed desired attitudes ${ }^{23}$.

Motivation and job satisfaction are interconnected and rewards and recognition have directly linked with motivation and job satisfaction of employees. As reward and recognition bring change in teachers' motivation and job satisfaction definitely put positive effects as well ${ }^{24}$.

As the two-factor theory compared to education, if institution betterment depends basically on the latest teaching strategies, customs to increase teacher motivation and worth and capabilities should be the central part upon which administration should focus. As other institutions and depart- ments, likewise special education institutions have impact of reward and recognition in combination with other factors that can have an effect on teachers' motivation and job satisfaction. And there is an important link between recognition and reward and that between job satisfaction and motivation of teachers' work ${ }^{25}$.

\section{Job Satisfaction}

The researchers have reviewed literature that investigates the factors and indicators of job satisfaction. Teachers' motivation and job satisfaction influences the career or professional patterns of teachers. They described their findings that essential indicator to high level of job satisfaction are to teach children especially where educator have ability to develop firm relationship, the intellectual confront of teaching and teacher's autonomy and self-determination ${ }^{26}$.

De Beer $^{27}$ describes the factors that influence job satisfaction within education by teacher's experiences, qualities, as well as emotional, physical, economic factors. So, if a teacher is satisfied with his or her work to the institutional objectives, an intrinsic reward is perceived in this way. And if a teacher feels that their particular job status is attained or recognized in society, a high degree satisfaction will be achieved.

According to Billingsley ${ }^{28}$, there are two factors of job satisfaction that is intrinsic and extrinsic factors. Intrinsic factors are non- material recognition for work or job it comprises of motivation for work in an institution. When teacher work within an intuition then the work environment, work conditions and supervisions by the administrators all these contribute to extrinsic factors.

Inspite of many other factors that influence the job satisfaction the effective supervision is also very effective. The competence of leaders and administrators has influence on working environment of an institution ${ }^{29}$

Linking these needs to the perception of special educators, it seems that teachers who are highly remunerated and can afford a high standard of living, have their hygiene or lower order needs met.

Special educators, however, must have motivators or higher-order requirements. So, researchers planned discussion around the concepts of rewards and recognition, responsibility, work autonomy, advancement, power and growth, achievement and self-actualization ${ }^{30}$.

The topic has grasped the concentration of the researchers' world over since decades, but it is a melancholy that no proper attention has been given to it in the Punjab province especially with the reference of special educators. Therefore, the 
present study is an effort to fill this gap and provide some qualitative insight into the depth of the matter and explore factors causing motivation and job satisfaction for teachers of hearing impaired students. The objectives of the study were to explore the factors of motivation and satisfaction among teachers of hearing impaired students. It also aimed to investigate the job dissatisfying factors among teachers of hearing impaired students, as well as to explore any differences among teachers about the perception of the motivating factors on the basis of gender

\section{METHODS \& MATERIALS}

Focus Group Discussions was used to understand the level of teacher motivation and job satisfaction amongst teachers of hearing impaired children. The participants of the study comprised of teachers of hearing impaired children, both male and female. The researchers conducted in depth interviews from these respondents. The majority of the teachers participating in the research were women (78\%), while male teachers comprised only $(22 \%)$ of the sample. This is in line with earlier studies indicates general tendency for more females than males to work at special education schools. Nine teachers were selected as participants of this FGD. Researchers conducted face to face interviews with teachers of hearing impaired children. Questions were fairly open-ended, with the aim to provide them with an opportunity to talk and share experiences.

\section{RESULTS AND DISCUSSION}

The participants of this research study consist in teachers of hearing impaired children, both male and female. The researchers conducted in depth interviews from these respondents. The demographic information regarding the participant and the results of this study are presented for in depth understanding of the problem.

Almost $89 \%$ of the participants had a Masters Level Degree as their highest qualification. Almost every teacher (100\%) had any professional degree as well. Only one participant (11\%) being vocational training instructor had less than Master Level Degree qualification. This shows that almost all the participants were true professionals in the field of special education.

The participants differ with respect to their teaching experiences. Both the male participants had almost ten years teaching experience. Among female participants two (28\%) of them had over twenty years of teaching experience. One of them (14\%) had over fifteen year's teaching experience whereas four $(57 \%)$ of the female participants had over 10 years teaching experience. Among the respondents, seven (78\%) were married and two (22\%) were unmarried.
The researchers discussed different aspects to investigate the factors of motivation and satisfaction to special educators. Researchers started the discussion to ask about motivation in their opinion.

\section{Stress Level Serving the Hearing Impaired}

The researchers ware interested to inquire whether the respondents feel any type of stress during their service as special education teacher. Both the male participants (100\%) claimed that they do not feel any type of stress while serving the disabled children. However married female $(n=5)$ teachers replied that they felt very disturbed during their pregnancies. They were suspecting that their new born babies might not get some type of disabilities as the result of their presence all the daylong in disabled environment. One of the senior respondents said:

Being a teacher of disabled children when I was pregnant and I could not sleep at night, I used to think that may be my baby born disabled because I spent time with disabled children and it could create a bad impact on my baby. This perception highly dissatisfied and created a stress for me. So teaching to special children is not as easy as people use to think.

And when their baby is not at school going age, they remained afraid to take him with them. They feel that at this stage, socialization with disabled children can create some problems in their own children. Another the female responded in this regard;

When my son reached school going age, I hired a teacher for tuition. My son was slow to learn at that initial stage. His teacher said that as you are a teacher of hearing impaired children, it created a bad impact on your child. I think he is not a normal baby. It created high stress in my mind but after some days I realized it was only teacher's misperception.

This discussion proves that stress level in married women is very high especially during pregnancy. It may affect negatively their motivation toward their job. They feel high level of stress, they remain afraid to become mother of a child with disabilities. But it's just their perception. It never happened in any case.

\section{Recognition as Special Education Teacher}

In many developing countries, teaching has historically enjoyed a large degree of reputation and prestige. Today, however, many teachers feel that the respect for their profession is decreasing in the eyes of students, parents, government, and the larger society.

Recognition or reputation is a highly motivating 
factor in every job. When researchers asked about their job status in society after actually entrance into this job, varied responses emerged. Almost 100\% participants considered social recognition among major motivating factor. About $43 \%$ of the female and $100 \%$ of the male participants which account for $56 \%$ of the total participants are of the view that they are satisfied with their status and enjoy social recognition in this field. One of the male participants stated:

In my point of view, motivation is most important thing to educate persons with hearing impairment. I will prefer again to become special educator because in our society majority have perception that teaching is suitable for female but being a male I joined it because it is source to attain moral values and satisfaction to serve persons with disabilities. No doubt people usually dishearten, even my own family used to say that instead of teaching if you join sports you can get better respect but I am satisfied with my profession.

However, $57 \%$ of the female teachers think that they had a charm of gazetted post their dream about a social status shattered after joining this profession. They are not given much importance in spite of high grade salaries. Even a policeman is more influential than a gazetted teacher. In the words of senior most teacher;

After serving 20 years I feel there is no admiration in this field, when I move in our society people used to says she is teacher of deaf and dumb, peoples make fun of it. I feel highly dissatisfied with it. .

As per discussion and responses it can be concluded that in special education gazetted post and religious satisfaction to teach children's with hearing impairment motivates teachers to serve in special education. However, a little recognition at the hands of society is availed by the teachers. But at the same time, this profession is very suitable for female especially as they enjoy more professional status, self-esteem, and better pay. Many teachers feel that another way to increase societal respect for teaching is to improve the public image of their profession by making the public more aware of the actual conditions they face.

\section{Role of Administrator}

Administrator has primary role in every organization. Administrator (often principal/head teacher in the field of education) plays a vital and leading role to achieve the organizational objectives in their true spirit. Research shows that when administrators use tactics to increase teacher empowerment, teacher morale increases. In schools where teachers are empowered to be leaders, the focus of control changes from the principal to the teachers.

During the discussion of the study, $100 \%$ respondents were found to admit the leading role of administration for the better motivation of the teachers. One of the participants said;

Administrator should be highly motivated and have characteristics of a good leadership. It can increase motivation level among all teachers.

But, at the same time majority (89\%) of the participants feel that they never found any good administrator who encouraged and motivated them for better working. Every principal was authoritative in his behavior and tried to impress the employees with help of political or bureaucratic power. One of the male respondent claims that he is very dissatisfied with this situation and wants to quit this profession only due to absence of motivation on the part of administration. In his own words;

I think a good leader/Administrator can play a very important role regarding motivation. If the boss is highly motivated he can motivate his staff. But if boss have no motivation, or have low caliber he creates dissatisfaction among staff, he can never acquire good results. Under the control of incompetent and low motivated leader. The satisfaction level of employees will be low. Because of incompetent leader I have been thinking since last year to replace my services at other places.

A female respondent stated:

A well motivated administrator can get $100 \%$ better results than unmotivated and undirected leader. It's my life experience. I managed 100 children in Faisalabad, but I can't manage 6 children from last 6 years because of low motivation level of administration. In our professional routines administrator plays a vital role.

In government sector, departmental authorities also play an imperative role which may be the source of motivation for teachers or otherwise. As the senior most teacher claims;

Department can play very important role to create motivation and satisfaction if all rules and regulation are observed and implemented properly. Specially properly recognized status of special educator then proper promotion channels organized by departments. It must evaluate motivation level in employees.

So, it can be concluded that $100 \%$ of the teachers experience that a learned and helping administrator can create better environment in organization and will be the source of motivation for teachers. However, $89 \%$ of the participant claimed that in their teaching life, they rarely met any competent organizational leader who motivated them for better working. 


\section{Perceived Motivation before Entering into Job}

The researchers started the discussion with the question that what was their perception about job as teacher of hearing impaired children before actually entering into this job. Almost all the participants (100\%) agreed to the senior most participant's answer that they felt highly motivated toward this job due to many factors. She further elaborated that charm of a gazetted post, high salaries and enormous buildings of special education institutes were among the motivating factors which attracted them to join their jobs. In her own words:

I think it is motivation which pushes us to join special education, gazetted post attracts us otherwise we can join general education.

There was no difference in the opinion of male and female participants that they perceived this job as most advantageous and were motivated towards it due to high salaries and other perceived compensations.

Religious and moral obligation also serves as motivational factor to adopt teaching to special children. About (22\%) of the participants comprising both genders consider religious rewards as a motivational factor, as one of the female respondents' states;

For the will of Allah serve these students because I think it is blessing of Allah that He chose me to serve these children with hearing impairment.

Most of the teachers described their perception about motivation in their own way. According to the above statements about motivation, it can be concluded that in special education gazetted post and religious satisfaction to teach children's with hearing impairment motivates teachers to serve in special education.

\section{Political Concern in Recruitments}

Recruitment is the corner stone of the organizational atmosphere. New blood in the form of fresh recruitment always helps organizations better cope with new challenges. However, sometimes political figures try to get recruitment according to their own will without fulfilling the necessary requirements. In this way, the newly inducted workforce is not professional in the true spirit and fails to produce required results.

Almost $100 \%$ of the participants are against the political recruitment in the field of special education. They think that personnel inducted politically do not fulfill their duties, rather they remain at the homes of their political leadership. In the word of a female respondent;

Political interference in recruitments is like an open play of merit. Hardworking candidates remain far behind replacing the recommended ones. Political approach should be discouraged from teaching profession. Employees who get job with political approach create dissatisfaction in others. It confirms that he has no ability to perform well, so he uses approach. When he joins job he does not perform his duties. He thinks he has a good political approach so no one can say anything to him.

Another male respondent also describes this situation in his own words:

Political approach in recruitment creates a very bad impact in all departments. Politically recruited employees do not perform their duties and they always use political pressure in case of any explanation. Mostly politically recruited employees are always irregular in their duties and they just get pay

So, it is concluded with the help of these detailed responses that $100 \%$ of the participants are against any political interference in the recruitment process. Political involvement lessens the motivational level of the workforce already trying to serve the children with hearing impairment.

\section{Remuneration and Incentives for Teachers of Hear- ing Impaired Children}

A review of the literature shows that there is a great association between different kinds of incentives and motivation level of employees all over the world. Better the incentives, better the motivation level. When the participants were asked whether salary package and pay scale attracted them toward the job, $100 \%$ of the participants claimed that monetary incentives are source of motivation. But they refused to admit them as the single basis for motivation. One of the male participants said;

The double salary in this field it motivated me to join the field of special education. Otherwise, I would have opted to join the field of general education where there are no disable students.

So, it can be concluded that $100 \%$ of the participants are of the view that remuneration and incentives increase the motivation of the employees.

\section{Inter Personal Relation with Colleagues}

Inter personal relationship with colleagues serves as important motivating factor for teachers. Almost all the respondents (100\%) were of the view that healthy relationship of colleagues creates an environment which urges and motivates teacher to reach up to the maximum level of performance which finally provides everyone some level of internal satisfaction. Some of the responses are given below: 
Interactions between teachers help in sorting out challenging tasks. By collaborating with each other teacher can plan a program for students and Positive relation with colleagues motivates you.

\section{Triumphs of Students}

The researchers urged to know that what should be that factors which suppress the job dissatisfaction and how do teachers feel job satisfaction. In this regard a female responds that,

The achievements of my students in their life motivate me to work even harder with special students so that they become active members of our society. If govt. wants to see highly motivated teachers in schools then, all issues which create dissatisfaction in employees should be resolved.

Almost $100 \%$ teachers agree to this response. All of them respond that when they see their special student a worthy member of society having a status they feel real inner deep satisfaction.

\section{Job Dissatisfying Factors}

The researchers sorted out following job dissatisfying factors:

- Lack of appreciation

- Stress level serving the disabled

- Unofficial duties

- Distracting teacher during period while assigning extra duties

- Lack of Training and Workshops

- Poor personal relationship with head

- Low job status

- Low Respect level

\section{CONCLUSION}

The participants conveyed additional qualitative information about teacher motivation and job satisfaction in focus group discussion. All teachers share very general characteristics and sources of motivation, they also bear their own individual motivations for becoming a teacher and value sources of motivation differently. Researchers distinguished that teachers joined the profession for a variety of different reasons; and that a given factor or framework category could motivate one teacher while having little effect on another. The researchers concluded that in special education gazetted post and religious satisfaction to teach children's with disabilities motivates teachers to serve in special education. Recognition and prestige is a highly motivated factor in every job. Nowadays, however, many teachers feel that the respect for their profession is decreasing in the eyes of students, parents, government, and the larger society.

Other important factors in teacher motivation pointed out by the interviewees included the role of department, supervisors, emphasis on outcomes versus processes, minimizing political interference, teacher networks and mentoring, training, treating teachers as equal partners, and provision of teachers" basic needs.

The researchers analyzed during discussion that stress level in married women is very high specially during pregnancy they feel high level of stress, they afraid to become a mother of child with hearing impairment. Although it's just their perception but it highly dissatisfies them.

The researchers concluded that management plays a vital role in motivation and job satisfaction of teachers. A Head of institution should possess all the qualities of leadership and create an environment where all employees feel satisfaction in this way they love to work. The satisfaction level of employees under the control of incompetent and low motivated leader will be low so according to respondents' motivation by leader or head is directly proportional to the motivation and job satisfaction of employees.

The researcher depicted the experiences of respondents that when colleagues work collaboratively for the sake of their students then positive results can be achieved as achievements demand devotion of teachers. Likewise appraisal practice by the administrators highly motivates the teachers to their work and if government removes all the dissatisfying factors then motivation level and job satisfaction among teachers can be achieved simultaneously.

\section{RECOMMENDATIONS}

The researchers present following recommendations according to the above Focus Group Discussion:

- A perfect environment of working is the dream of teachers, therefore political interference should be avoided and favoritism that dishearten the hard workers should be abstained

- Sitting arrangements in the classrooms should be according to the need of the students and all the resources that a teacher could use should be provided.

- All classrooms should be equipped with necessary equipment for hearing aids.

- Encourage the spirit of enquiry and creativity in teachers

- Researchers noted that by creating awareness in society about special children the factor of mocking at special educators can be settled down.

- The researchers emphasized to help teachers to fit into the social life of the community and society at large.

- It is highly recommended that teacher should be assigned subjects according to their specializations 
as irrelevancy creates dissatisfaction.

- Trainings and workshops should be arranged periodically to update the knowledge of teachers. - Unofficial duties of teachers should be discouraged to preserve the status of teachers in our society.

- Researchers idealized that proper departmental policies should be designed, observed and implemented and promotion channel should be proper as it is the fundamental right of the teachers or employees.

\section{REFERENCES}

[1) Franken RE. Human Motivation. Brooks. Cole Publishing Co; 1994.

[2] Singh G, DeNoble A. Early retirees as the next generation of entrepreneurs. Entrepreneurship theory and practice. 2003; 27(3):207-26.

[3] Tsigilis N, Zachopoulou E, Grammatikopoulos V. Job satisfaction and burnout among Greek early educators: A comparison between public and private sector employees. Educational Research and Review. 2006; 1 (8):256-61.

[4] Shah MJ, Rehman M, Akhtar G, Zafar H, Riaz A. Job satisfaction and motivation of teachers of public educational institutions. International Journal of Business and Social Science. 2012; 3(8):271-81.

[5] Alzaidi AM. A Qualitative Study of Job Satisfaction among Secondary School Head Teachers in the City of Jeddah, Saudi Arabia. ARECLS. 2008; 4:1-15.

[6] Baron RA. Personality and organizational conflict: Effects of the Type A behavior pattern and self-monitoring. Organizational Behavior and Human Decision Processes. 1989; 44(2):281-96.

[7] Ololube NP. Teachers Job Satisfaction and Motivation for School Effectiveness: An Assessment. Online Submission. 2006.

[8] Koustelios A, Theodorakis N, Goulimaris D. Role ambiguity, role conflict and job satisfaction among physical education teachers in Greece. International Journal of Educational Management. 2004; 18(2):87-92.

[9] Dinham S, Scott C. Moving into the third, outer domain of teacher satisfaction. Journal of Educational Administration. 2000; 38(4):379-96.

[10] Oshagbemi T. Overall job satisfaction: how good are single versus multiple-item measures. Journal of Managerial Psychology. 1999; 14(5):388-403.

[11] Myers DG, Diener E. The pursuit of happiness. Scientific American. 1996; 274(5):70-2.

[12] Locke EA. The nature and causes of job satisfaction. Handbook of industrial and organizational psychology. 1976; 1:1297-343.

[13] [13] Evans L. Understanding teacher morale and job satisfaction. Teaching and Teacher Education. 1997; 13(8):831-45.

[14] Menlo A, Poppleton P. A Five-country Study of the Work Perceptions of Secondary School
Teachers in England, the United States, Japan, Singapore and West Germany (1986-88). Comparative Education. 1990; 26(2-3):172-82.

[15] Heward WL, Chance P. Introduction: Dealing with what is. The Behavior Analyst. 2010; 33(2):145.

[16] Panda KC. Education of Exceptional Children: A Basic Text on the Rights of the Handicapped and the Gifted: Vikas Publishing House Pvt Ltd; 1999.

[17] Schunk DH. Self-efficacy and academic motivation. Educational psychologist. 1991: 26(3-4):207-31.

[18] Jelencic M. Motivation theories-an overview. 2010.

[19] Cranny C, Smith PC, Stone E. Job satisfaction: How people feel about their jobs. 1992.

[20] Ayub N, Rafif S. The relationship between work motivation and job satisfaction. Pakistan Business Review. 2011; 13.

[21] Herzberg F. Motivation-hygiene theory. chair in human resources at the State University of New York-Buffalo and was faculty director of the Center for Entrepreneurial Leadership there Previously he was Research Professor of Management at Georgia State University He has written over fifty books and over 135 other publications. 2005: 61.

[22] Weinstein M. Managing to Have Fun: How Fun at Work Can Motivate Your Employees, Inspire Your Coworkers, and Boost Your Bottom Line: Simon and Schuster; 1997.

[23] Fisher RJ, Ackerman D. The effects of recognition and group need on volunteerism: A social norm perspective. Journal of Consumer Research. 1998; 25(3):262-75.

[24] Ali R, Ahmed MS. The impact of reward and recognition programs on employee's motivation and satisfaction: an empirical study. International review of business research papers. 2009; 5(4):270-9.

[25] Ololube NP. Teachers Job Satisfaction and Motivation for School Effectiveness: An Assessment. Online Submission. 2006.

[26] Spear LP. The adolescent brain and age-related behavioral manifestations. Neuroscience \& Biobehavioral Reviews. 2000; 24(4):417-63.

[27] De Beer LT, Pienaar J, Rothmann Jr S. Investigating the reversed causality of engagement and burnout in job demands-resources theory. SA Journal of Industrial Psychology. 2013; 39(1):01-9.

[28] Billingsley BS. Special education teacher retention and attrition a critical analysis of the research literature. J Spec Educ. 2004; 38(1):39-55.

[29] Sargent T, Hannum E. Keeping teachers happy: Job satisfaction among primary school teachers in rural Northwest China. Comparative education review. 2005; 49(2):173-204.

[30] Aziz A, Saeed M, Ch FA. An Exploratory Study of Teachers' Motivation and Job Satisfaction in Special Education, Lahore, Pakistan. Social Sciences Review. 2014; 2(1):21-39. 